\title{
CHARACTERIZATION OF FINE-GRAINED CERAMIC MATERIAL FOR ENVIRONMENTAL-FRIENDLY APPLICATIONS IN THE BUILDING SECTOR
}

\author{
MILOŠ JERMAN, VRATISLAV TYDLITÁT, MARTIN KEPPERT \& ROBERT ČERNÝ \\ Department of Materials Engineering and Chemistry, Faculty of Civil Engineering, \\ Czech Technical University in Prague, Czech Republic.
}

\begin{abstract}
A characterization of the properties of waste ceramic powder that is generated during advanced hollow brick production is presented. The main aim of the study is to facilitate environmental-friendly applications of the ceramic in the building sector. Therefore, its reactivity with cement is analyzed using isothermal calorimetry. Experimental results show that the investigated waste fine-grained ceramic material has good potential in application in concrete mix design from both environmental and economical perspectives.
\end{abstract}

Keywords: calorimetry, cement, ceramic powder, supplementary cementing material.

\section{INTRODUCTION}

Production of Portland cement is a significant contributor to $\mathrm{CO}_{2}$ emissions. Therefore, it is very reasonable to use blended cements in which a part of the clinker is replaced by supplementary cementing materials (SCM). Various investigators have reported the use of SCM in fly ash [1, 2], metakaolin [3-5], zeolite [6], silica fume, or other materials like agricultural wastes. In this study, the use of ceramic powder as an SCM is analyzed.

The production of red-clay hollow bricks is one of the causes of ceramic waste generation, which gained importance continuously during the past decade or two. The increasing requirements for thermal insulation properties of building envelopes that are compliant with national standards, particularly in Europe, led the brick producers to reduce the production of common solid bricks. Brick blocks with more or less complex systems of internal cavities replaced traditional bricks and became dominant in the building ceramics market.

During the production of hollow bricks, the amount of scrap generated is similar to that obtained with traditional red-clay bricks. However, for advanced types of hollow brick blocks the total ceramic waste generation is higher. This is attributed to one of the current trends in the building sector, which is the use of thin joint technology in the construction of building envelopes. While during the past decades this technology was commonly used mainly for autoclaved aerated concrete, recently it has become popular also for hollow-brick-based envelopes. As the current technologies employed in hollow brick production do not make it possible to provide sufficiently smooth and even surfaces, the brick blocks have to be ground after leaving the production line. The grinding generates a significant amount of waste ceramic dust that is mostly landfilled although it has the composition and granulometry suitable for being used as a pozzolanic admixture to cement as an SCM. 
In the previous work done by other investigators it was reported that some other types of waste ceramic could be used as an SCM in lime mortar or in concrete due to their pozzolanic activity [7, 8]. In this article, a characterization of waste ceramic dust that is generated during advanced hollow brick production is presented. The aim of the study is to facilitate the environmental-friendly applications of the analyzed ceramic in the building sector.

\section{MATERIALS AND METHODS}

Ceramic dust was delivered by Heluz v.o.s. Its specific surface was $1,374 \mathrm{~m}^{2} \mathrm{~kg}^{-1}$; the grainsize distribution was very fine, with $\mathrm{d}_{50}=8.1 \mu \mathrm{m}$; and the density of the dust was 2,615 $\mathrm{kgm}^{-3}$. The chemical composition was determined by XRF analysis and is provided in Table 1. Portland cement CEM I 42.5 was used as the main binder in the blends, its chemical composition is also given in Table 1.

The composition of the studied cement pastes is shown in Table 2. The cement was replaced in a gradual way up to $60 \%$. The water/binder ratio was 0.5 for all pastes.

The course of the hydration heat as well as the total heat evolved during the hydration of cement and its blends were determined by an isothermal calorimeter, at $25^{\circ} \mathrm{C}$. The solid components were put into the mixing device and mixed at high speed for $1 \mathrm{~min}$. About $1 \mathrm{~g}$ of mixed blend was weighted and filled into a copper vessel, which was closed by a rubber cover and inserted into the calorimeter. A weighted syringe with water was placed near the reaction vessel, and so was a plastic tubule intended for paste mixing. All components were left for

Table 1: Composition of ceramic dust and cement.

\begin{tabular}{lcc}
\hline & ceramic dust & CEM I 42.5 \\
\hline $\mathrm{SiO}_{2}$ & 51.3 & 18.9 \\
$\mathrm{Al}_{2} \mathrm{O}_{3}$ & 20.0 & 4.2 \\
$\mathrm{Fe}_{2} \mathrm{O}_{3}$ & 6.0 & 3.8 \\
$\mathrm{CaO}$ & 11.5 & 62.4 \\
$\mathrm{MgO}$ & 4.5 & 1.0 \\
$\mathrm{~K}_{2} \mathrm{O}$ & 3.2 & 0.0 \\
$\mathrm{Na}_{2} \mathrm{O}$ & 1.3 & 0.0 \\
$\mathrm{TiO}_{2}$ & 0.8 & 0.8 \\
$\mathrm{SO}_{3}$ & 1.0 & 2.31 \\
\hline
\end{tabular}

Table 2: Composition of cement pastes.

\begin{tabular}{lcccc}
\hline & \multicolumn{4}{c}{ Composition $\left[\mathrm{kg} / \mathrm{m}^{3}\right]$} \\
\cline { 2 - 5 } Component & $\mathrm{C}$ & $\mathrm{CH} \mathrm{20}$ & $\mathrm{CH} \mathrm{40}$ & $\mathrm{CH} \mathrm{60}$ \\
\hline CEM I 42,5 & 385 & 347 & 308 & 231 \\
Ceramic dust & 0 & 38 & 77 & 154 \\
Water & 192.5 & 192.5 & 192.5 & 192.5 \\
\hline
\end{tabular}


about $1 \mathrm{~h}$ to stabilize the temperature. After stabilization, the calorimeter was opened and the water was added to the vessel. The paste was mixed by rotation of the plastic tubule for $30 \mathrm{~s}$, then the part of the tubule sticking out was cut off and the vessel was closed by a rubber plug; the calorimeter was closed by two lids. All measurements were performed for $140 \mathrm{~h}$. The time dependence of the heat power in $\mathrm{mW}$ obtained as the measurement output was used to calculate the specific hydration heat power in $\mathrm{mW} / \mathrm{g}$ and the specific hydration heat in $\mathrm{J} / \mathrm{g}[6]$.

\section{EXPERIMENTAL RESULTS}

The specific hydration heat power is shown in Fig. 1. The first maximum corresponding to the first phase of $\mathrm{C}_{3} \mathrm{~A}$ hydration occurred 3 minutes after mixing the solid components with water. This peak was influenced also by the wetting heat. The second peak reflecting the $\mathrm{C}_{3} \mathrm{~S}$ hydration was observed at 10-12 h. The specific hydration heat power significantly decreased with the increasing amount of ceramic dust. The maximum of the blend $\mathrm{CH} 60$, where $60 \%$ of cement was replaced by ceramic dust, achieved only $44 \%$ of the reference cement. The third peak that corresponded to the second phase of $\mathrm{C}_{3} \mathrm{~A}$ hydration was observed at about $45 \mathrm{~h}$, but it was not very distinct.

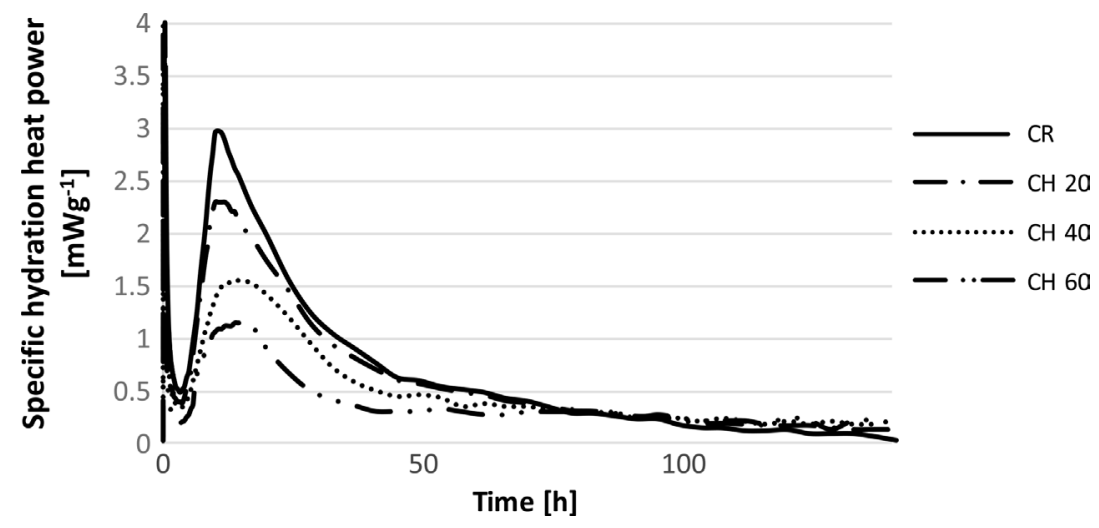

Figure 1: Specific hydration heat power per $1 \mathrm{~g}$ of blended cement.

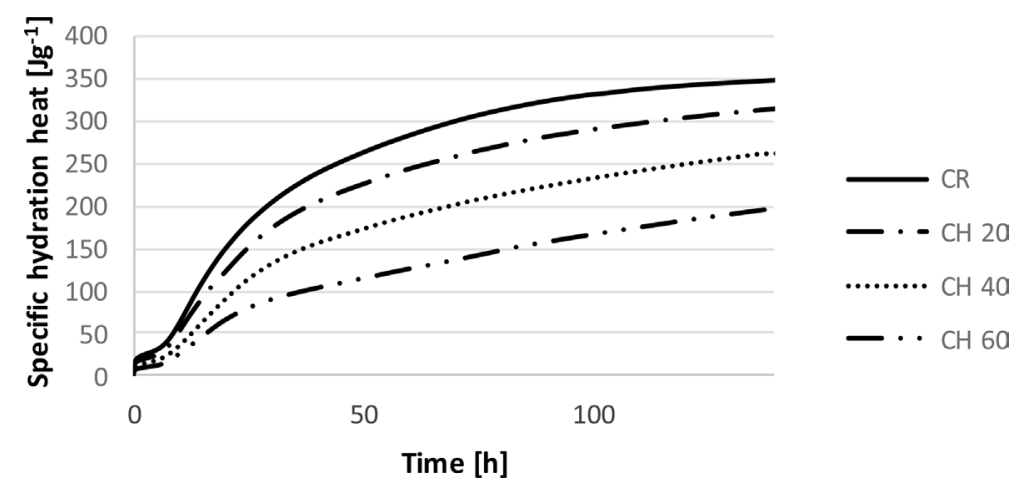

Figure 2: Specific hydration heat per $1 \mathrm{~g}$ of blended cement. 
The total hydration heat is shown in Fig. 2. The highest total hydration heat after $140 \mathrm{~h}$ achieved the Portland cement, $349 \mathrm{Jg}^{-1}$. With increasing dosage of ceramic dust, the specific hydration heat decreased: $\mathrm{CH} 20$ achieved $315 \mathrm{Jg}^{-1}$, CH $40243 \mathrm{Jg}^{-1}$, and $\mathrm{CH} 60198 \mathrm{Jg}^{-1}$. The total hydration heat decreased fast for a replacement level higher than $20 \%$. It agreed well with the results of the measurements of compressive strength of concrete where the blended cement with ceramic dust was used [9].

The effect of the ceramic powder on the hydration heat development in the blended cements was expressed (per $1 \mathrm{~g}$ of ceramic) using the difference specific hydration heat power, $N_{\mathrm{d}}$, and difference specific hydration heat, $Q_{\mathrm{d}}$,

$$
N_{D}(x)=\frac{\left[N(R C L x)-\left(1-\frac{x}{100}\right) * N(R L)\right.}{\frac{x}{100}}
$$

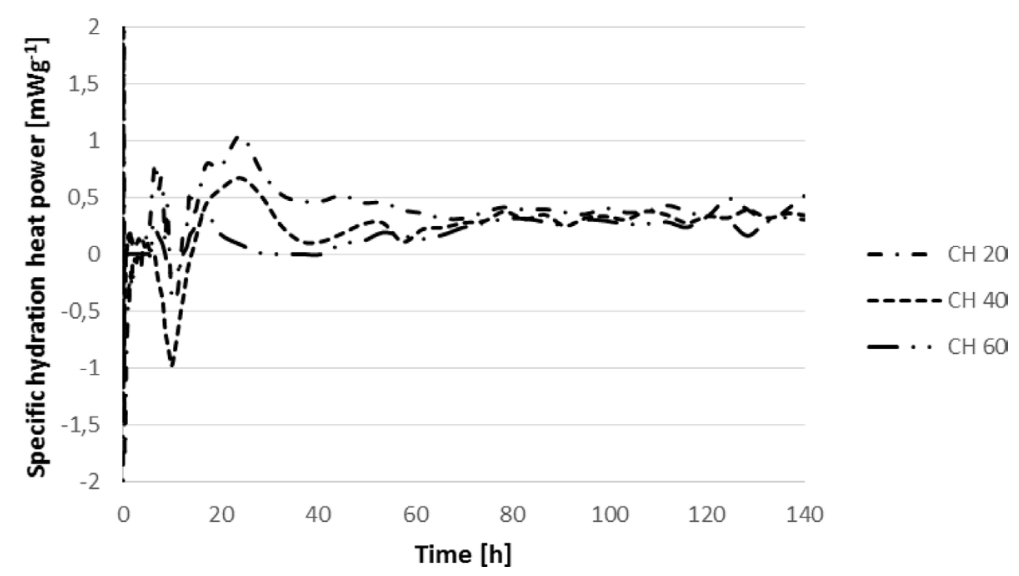

Figure 3: Difference specific hydration heat power per $1 \mathrm{~g}$ of ceramic.

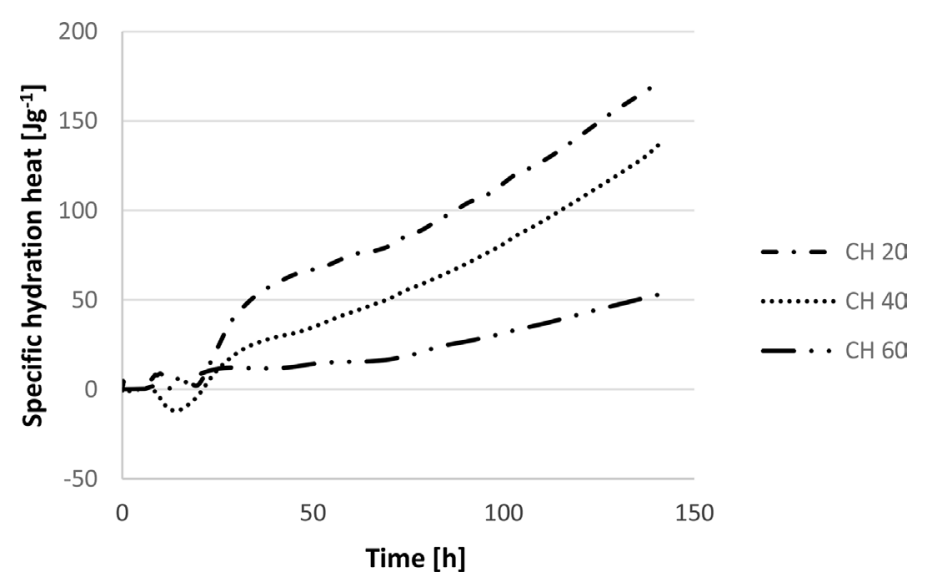

Figure 4: Difference specific hydration heat per $1 \mathrm{~g}$ of ceramic. 


$$
Q_{D}(x)=\frac{\left[Q(R C L x)-\left(1-\frac{x}{100}\right) * Q(R L)\right.}{\frac{x}{100}}
$$

where $\mathrm{x}$ is the content of ceramic dust in mixture CLx in \%.

Figure 3 shows that up to $18 \mathrm{~h}$ the effect of ceramic dust on the hydration heat development was negative but then it increased rapidly. The highest effectiveness of the application of the ceramic in the blended binders was when it achieved $\mathrm{CH} 20$ and $\mathrm{CH} 40$, and the lowest had the blend where $60 \%$ of cement was replaced. The additional hydration heat evolved, apparently, due to the pozzolanic reaction of $\mathrm{Al}_{2} \mathrm{O}_{3}, \mathrm{SiO}_{2}$, and $\mathrm{Fe}_{2} \mathrm{O}_{3}$ that were incorporated in the ceramic dust under alkaline conditions of the cement-based system.

The different specific hydration heat is shown in Fig. 4. Up to $25 \mathrm{~h}$ it was close to zero values for all blends but then it increased rapidly due to the initiated pozzolanic reaction. The highest $Q_{\mathrm{d}}$ value after $140 \mathrm{~h}$ achieved the blend CH $20-172 \mathrm{Jg}^{-1}, \mathrm{CH} 40 \mathrm{had} 129 \mathrm{Jg}^{-1}$, and $\mathrm{CH} 60$ only $53 \mathrm{Jg}^{-1}$.

\section{CONCLUSIONS}

The measurements of hydration heat development in the Portland cement- ceramic blended binders showed that incorporating the waste ceramic dust generated during hollow brick production into the blends was most effective up to $20 \%$ of mass of Portland cement. However, the application of the ceramic up to a $40 \%$ replacement level could still be considered acceptable, from an economical and environmental perspective. Therefore, it could be concluded that the analyzed waste ceramic has good potential in application in concrete mix design. The use of ceramic powder as partial replacement of either Portland cement in concrete or lime in pozzolanic plasters on one hand converts landfilled waste material to a valuable $\mathrm{SCM}$, and, on the other hand, contributes to a decrease in the overall energy consumption and $\mathrm{CO}_{2}$ emission, which accompanies the Portland cement and lime production. The proposed solution is also cost-effective because the waste ceramic dust does not need any further processing and can be used in the form in which it is obtained from the production line.

\section{ACKNOWLEDGMENT}

This research has been supported by the Czech Science Foundation, under project No 16-02862S.

\section{REFERENCES}

[1] Wzorek, M., Baran, T. \& Ostrowski, M., The influence of ash absorption from secondary fuels combustion on clinkering process and hydraulic activity of Portland cement clinker. Cement Wapno Beton, 18, pp. 207-215, 2013.

[2] Chau, C.K., Chan, J. \& Li, Z., Influence of fly ash on magnesium oxychloride mortar. Cement \& Concrete Composites, 31, pp. 250-254, 2009. http://dx.doi.org/10.1016/j.cemconcomp.2009.02.011

[3] Sabir, B.B., Wild, S. \& Bai, J., Metakaolin and calcined clay as pozzolans for concrete: a review. Cement \& Concrete Composites, 23, pp. 441-454, 2001. http://dx.doi.org/10.1016/S0958-9465(00)00092-5

[4] Vejmelková, E., Pavlíková, M., Keppert, M., Keršner, Z., Rovnaníková, P., Ondráček, M., Sedlmajer, M. \& Černý, R., High Performance concrete with czech metakaolin: 
experimental analysis of strength, toughness and durability characteristics. Construction and Building Materials, 24, pp. 1404-1411, 2010.

http://dx.doi.org/10.1016/j.conbuildmat.2010.01.017

[5] Rojas, M.S. \& Cabrera, J., The effect of temperature on the hydration rate and stability of the hydration phases of metakaolin-lime-water systems. Cement and Concrete Research, 32, pp. 133-138, 2002.

http://dx.doi.org/10.1016/S0008-8846(01)00642-1

[6] Tydlitát, V., Zákoutský, J. \& Černý, R., Early-stage hydration heat development in blended cements containing natural zeolite studied by isothermal calorimetry. Thermochimica Acta, 582, pp. 53-59, 2014.

http://dx.doi.org/10.1016/j.tca.2014.03.003

[7] Sánchez-Moral, S., Luque, L., Canaveras, J.-C., Soler, V., Garcia-Guinea, J. \& Aparicio, A., Lime pozzolana moratars in Roman catacombs: composition, structures and restoration. Cement and Concrete Research, 35, pp. 1555-1565, 2005. http://dx.doi.org/10.1016/j.cemconres.2004.08.009

[8] Pacheco-Torgal, F. \& Jalali, S., Reusing ceramic wastes in concrete. Construction and Building Materials, 24, pp. 832-838, 2010.

http://dx.doi.org/10.1016/j.conbuildmat.2009.10.023

[9] Vejmelková, E., Keppert, M., Rovnaníková, P., Ondráček, M., Keršner, Z. \& Černý, R., Properties of high performance concrete containing fine-ground ceramics as supplementary cementitious material. Cement and Concrete Composites, 34, pp. 55-61, 2012.

http://dx.doi.org/10.1016/j.cemconcomp.2011.09.018 